\title{
Mineral nutrition and yield of sweet potato according to phosphorus doses
}

\author{
Sandra Maria da Costa Cruz', Arthur Bernardes Cecílio Filho², \\ Alexsandra Sousa Nascimento', Pablo Forlan Vargas ${ }^{3 *}$ \\ 'Federal Institute of Education Science and Technology of Maranhão, São Luis, MA, Brazil \\ 2Paulista State University, Jaboticabal, SP, Brazil \\ ${ }^{3}$ Paulista State University, Registro, SP, Brazil \\ ${ }^{*}$ Corresponding author, e-mail: pablo@registro.unesp.br
}

\begin{abstract}
The sweet potato is a vegetable with potential for expansion of its production area, due to its versatility of use, as it can be used as food, feed and biofuel. However, there is limited information on the mineral nutrition and performance of this vegetable in response to fertilization, especially phosphorus, which is a nutrient with strong interaction with the soil. Given the above, the aim of the present study was to evaluate phosphorus fertilizer levels on growth, mineral nutrition and sweet potato productivity. An experiment carried out from September 3, 2011 until January 3, 2012, in São Luis-MA, aimed to evaluate phosphorus fertilizer levels on growth, mineral nutrition and productivity of sweet potato plants. The experimental design was a completely randomized blocks with four replications. Harvest took place 123 days after seedling transplantation. Phosphorus doses influenced the P level in the soil, plant aerial and root dry matter, total and commercial productivities, and the accumulation of $\mathrm{P}$ in the plant aerial part dry matter, tuberous roots and the total plant. The foliar $\mathrm{P}$ content was verified to follow a linear adjustment to the doses of $\mathrm{P}_{2} \mathrm{O}_{5}$ whereas total and commercial productivities of roots followed a quadratic adjustment. Maximum productivity $\left(1.68 \mathrm{~kg} \mathrm{~m}^{-2}\right)$ resulted when the $\mathrm{P}_{2} \mathrm{O}_{5}$ dose was $191 \mathrm{~kg} \mathrm{ha}^{-1}$. The optimal economical dose was $104 \mathrm{~kg} \mathrm{P}_{2} \mathrm{O}_{5} \mathrm{ha}^{-1}$, that is, $54 \%$ of the dose that resulted in the highest commercial productivity.
\end{abstract}

Keywords: Ipomea batatas, phosphorous fertilization, economical dose.

\section{Nutrição mineral e produtividade da batata-doce em função de doses de fósforo}

\section{Resumo}

A batata-doce é uma hortaliça com potencial de expansão de suas área de produção, devido a sua versatilidade de uso, podendo ser utilizada como alimentação humana, animal e biocombustível. Contudo, há escassez de informações sobre a nutrição mineral e o desempenho desta hortaliça em resposta à adubação, especialmente fósforo, que é um nutriente com forte interação com o solo. Desta forma, um experimento realizado entre 3/9/11 e 3/1/12, em São Luís-MA, objetivou avaliar doses de adubação de fósforo sobre o crescimento, nutrição mineral e produtividade de plantas de batata-doce. O delineamento experimental foi o de blocos ao acaso com quatro repetições. A colheita ocorreu 123 dias após o transplante das mudas. As doses de fósforo influenciaram o teor de P no solo, matéria seca da parte aérea, matéria seca da raiz, a produtividade total, e os acúmulos de P na matéria seca da parte aérea, raiz e total da planta. Houve ajuste linear para o teor foliar e ajuste quadrático para a produtividade comercial de raízes, sendo que a máxima produtividade $\left(1,68 \mathrm{~kg} \mathrm{~m}^{-2}\right)$ foi obtida com a dose estimada de $191 \mathrm{~kg} \mathrm{ha}^{-1}$ de $\mathrm{P}_{2} \mathrm{O}_{5}$. A dose ótima econômica foi de $104 \mathrm{~kg} \mathrm{ha}^{-1}$ de $\mathrm{P}_{2} \mathrm{O}_{5}$, correspondendo a $54 \%$ da dose que maximizou a produtividade comercial.

Palavras-chave: Ipomoea batatas, fertilização fosfatada, dose econômica 


\section{Introduction}

The sweet potato (Ipomoea batatas) is a crop with great potential, owing to it being one of the vegetables that produces the most energy per area (Mukhopadhyay et al., 2011) and it is also rich in antioxidants, vitamin C, beta-carotene, boron, calcium, copper, folic acid, iodine, iron, magnesium, manganese, niacin, phosphorus, potassium, sulfur, tryptophan, tyrosine and zinc (Gad \& Kandil, 2008).

In Brazil, the sweet potato is the fourth most consumed vegetable, (Oliveira et al., 2005a), and is cultivated in all Brazilian states (Alves et al., 2009) throughout a total area, in 2012 , of 40,100 hectares, with an average yield of 12,1 tha-1 (IBGE, 2014), placing it among the six main vegetables, in area, grown in the country. However, because it is traditionally cultivated by small farmers and most of this production is dedicated to the local market or for their own consumption, in family farming the sweet potato has not received much attention from the Brazilian agricultural research community, notably regarding the knowledge of its nutritional demands and fertilizer recommendation criteria (Thume et al., 2013).

Thus, the low application of technology, especially that regarding the correct use of inputs, can be seen as an important factor in the low crop productivity (Silva et. Al., 2013).

Among the technologies that should be used by farmers, balanced soil fertilization should be adopted, which provides high yields combined with good profitability.

Among the essential elements for the growth and development of the sweet potato plant, phosphorus (P) stands out. This nutrient plays a key role in plant development because it acts in respiration, photosynthesis and the formation of pyrophosphate bonds that allow energy transfer. However, $\mathrm{P}$ is a naturally deficient nutrient in some soils, becoming a widespread problem in soil throughout the tropics (Bailey et. Al., 2009).

The sweet potato is very efficient in phosphorus absorption, but it is necessary to apply higher amounts of the element in readily available form due to the deficiency of this element in Brazilian soils and its high fixation by the soil colloids (EMBRAPA, 1995).

Positive results from phosphated soil fertilization on sweet potato performance are found in the literature. Oliveira et al. (2005b) in studies conducted in Areia-PB evaluating the phosphorus fertilization ranging from 0 to $400 \mathrm{~kg}$ $\mathrm{ha}^{-1} \mathrm{P}_{2} \mathrm{O}_{5}$, reported that total $\left(23.5+\mathrm{ha}^{-1}\right)$ and commercial $\left(18.9 \dagger^{-1} \mathrm{ha}^{-1}\right)$ production of sweet potato were reached with $\mathrm{P}_{2} \mathrm{O}_{5}$ doses 259 and $231 \mathrm{~kg} \mathrm{ha}^{-1}$, respectively.

Hameda et al. (2011) found significant increases in the total sweet potatoe yield from 13.8 tha $^{-1}$, at $15 \mathrm{~kg} \mathrm{ha}^{-1}$ of $\mathrm{P}_{2} \mathrm{O}_{5}$ to 16.14 t ha-1 when the $\mathrm{P}_{2} \mathrm{O}_{5}$ dose was $45 \mathrm{tkg} \mathrm{ha-1}$, i.e. an increase of $2.3+\mathrm{ha}^{-1}$.

Given the above, the aim of the present study was to evaluate phosphorus fertilizer levels on growth, mineral nutrition and sweet potato plant productivity.

\section{Material and Methods}

The study was conducted from September 3, 2011 to January 4, 2012, at the Federal Institute of Maranhão - IFMA - Maracanã Campus, located in the municipality of San Luis, located 2³6'35.94' ' South, 4415' $52.02^{\prime \prime}$ ' West, at an altitude of 34 meters.

The climate according to Thornthwaite classification is the type BI WA, characterized as humid, with moderate water deficiency in the winter, between the months of June and September.

The soil of the area is a dystrophic cohesive Red-Yellow Argisol of the Itapecuru Formation. The chemical characteristics and soil texture were measured previously to the installation of the study, through soil samples collected in the 0-20 cm layer. These samples were sent to the Soil Chemistry and Fertility Laboratory at the State University of Maranhão.

The analysis showed a soil texture with $6 \%, 8 \%$ and $86 \%$ clay, silt and sand, respectively. Chemical analysis showed: $\mathrm{pH}\left(\mathrm{CaCl}_{2}\right)$ 4.8; Organic matter $14 \mathrm{~g} \mathrm{dm}^{-3}$; $\mathrm{P}$ (resin) $14 \mathrm{~g} \mathrm{dm}^{-3} ; \mathrm{K}$, $\mathrm{Ca}, \mathrm{Mg}, \mathrm{Na}, \mathrm{Al}, \mathrm{Al}+\mathrm{M}$ and $\mathrm{CEC}$ were, respectively, $0.3,3.0,4.0,0.4,0.0,24.0,31.7 \mathrm{mmolc}^{-3}$ and base saturation was $24 \%$.

The study was conducted through a randomized block design, with six treatments 10 , 
$60,120,180,240$ and $300 \mathrm{~kg} \mathrm{ha}^{-1} \mathrm{P}_{2} \mathrm{O}_{5}$ ) with four replications.

The experimental unit area was $2.4 \mathrm{~m}$ wide and $3.5 \mathrm{~m}$ long comprising three windrows of soil spaced $0.80 \mathrm{~m}$ from each other with ten plants spaced at $0.35 \mathrm{~m}$. Data were collected only in the eight central plants of the center line of the plot, the useful area of the plot, the others being considered borders.

Liming and fertilization atplanting and in covering were carried out according to recommendations by Casali (1999). Liming was done in total area with lime containing $32 \% \mathrm{CaO}$ and $15 \% \mathrm{MgO}$, and RPTN of $95 \%$, to increase the soil base saturation $60 \%$ and $\mathrm{Mg}$ content

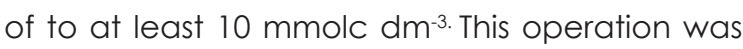
followed by plowing and harrowing, in order to incorporate the input.

Sixty days after liming, furrows, $20 \mathrm{~cm}$ deep, were opened and $30 \mathrm{~kg} \mathrm{ha}^{-1} \mathrm{~N}$ (urea), $90 \mathrm{~kg} \mathrm{ha}^{-1}$ of $\mathrm{K}_{2} \mathrm{O}$ (potassium chloride) and 10 † ha $^{-1}$ of cured cattle manure were applied. Fertilization with $\mathrm{P}$ was conducted according to the treatments to be tested, $0,60,120,180$, 240 and $300 \mathrm{~kg} \mathrm{ha}^{-1} \mathrm{P}_{2} \mathrm{O}_{5}$ using superphosphate as a source. As such, each plot was fertilized according to the experimental design, receiving all the phosphate fertilizer at planting. The windrows of soil were then manually raised with a hoe.

The Beauregard sweet potato variety was used, which is an American cultivar developed by the Lovisiana Agricultural Experiment Station. It was introduced in Brazil by the La Papa International Center (CIP), Peru. This cultivar has vegetative cycle between 90 and 130 days, in Maranhão. It has elongated, uniform roots and a smooth, red-purple skin. Internally it has an intense orange color, indicative of high beta-carotene content which characterizes it as biofortified.

Stems containing four buds were taken from the apical part of the mother plant, in the EMBRAPA experimental field in Coroatá, MA, and were placed in 50-cell polystyrene trays containing organic substrate. After 25 days transplantation to the windrows was carried out.

Irrigation was conducted according to crop nesessity. Topdressing was done applying
$30 \mathrm{~kg} \mathrm{ha}^{-1} \mathrm{~N}$, as urea, 30 days after transplanting (DAT). Pest control (whitefly and mealybug) was done chemically and invasive plant removal was conducted through three manual weedings, two weedings in the windrows, 30 and 60 DAT, and weeding between the windrows at 45 DAT.

At 60 DAT we evaluated (a) foliar $P$ content (TFP): Leaves from the middle third of the sweet potato foliage, i.e. the latest fully developed leaves were removed from eight plants per plot of the experimental unit. The collection was held at the beginning of the day, between 6 and 7 a.m.. Once collected, the leaves were washed with tap and deionized water to remove impurities. After excess water removal with a paper towel, the samples were placed in paper bags, identified and taken to dryi in a forced-air oven with circulation at $65^{\circ} \mathrm{C}$ until constant mass. Each sample was then ground in a Wiley mill. The preparation of the extracts for reading the $P$ content was performed according to the methodology of Battaglia et al. (1983).

At 123 DAT the sweet potato roots were harvested and the following evaluated:

(B) Aerial part dry matter (DMAP): the leaves and branches of the useful area of the plot were harvested, they were washed, deposited in paper bags and placed in a forced-air oven at $65^{\circ} \mathrm{C}$, until constant mass. Later they were weighed and values converted to $\mathrm{g} \mathrm{m}^{2}$.

(C) Dry matter of tuberous root (RDM): Two roots from the useful area were weighed, cut into small slices, placed in paper bags and dried in a forced-air oven with circulation at $65^{\circ} \mathrm{C}$ until constant mass. They were later weighed and values converted to $\mathrm{g} \mathrm{m}^{2}$.

(d) Total dry matter (TDM): Calculated by the sum of the DMAP + RDM.

(e) Total root productivity (TP): The roots were harvested from eight plants of the useful area, soon after being washed and sun-dried for one day, they were weighed and the values converted to $\mathrm{kg} \mathrm{m}^{-2}$.

(f) Commercial root production (CP): The harvested roots weighing between 80 and $800 \mathrm{~g}$ (EMBRAPA, 1995) were considered as commercial. Roots were weighed and the values converted to $\mathrm{kg} \mathrm{m}^{2}$.

(g) P accumulation: at harvest, the 
DMAP and RDM P content in the plant were analyzed using the methodology of Battaglia et al. (1983). Upon the results of the content and the dry masses of the parts in which they were determined, amounts of these nutrients accumulated in every plant part were obtained. The total amount accumulated in the plant was obtained by adding the amounts in the DMAP and RDM, whereas the nutrient export corresponded to the amounts in the RDM.

(h) Soil P content (TSP): After completion of the experiment, the central cultivation line (furrow) of each plot was sampled at five points. Simple samples were mixed for obtaining a composite sample, in which $\mathrm{P}$ content was evaluated.

(I) Optimal economical P dose: The optimal economic dose for the production of commercial roots was determined according to the methodology of Natale et al. (1996). An equivalence relation (RE) of 3.7 was obtained by the ratio between the average price of $1 \mathrm{~kg}$ of $\mathrm{P}_{2} \mathrm{O}_{5}(\mathrm{R} \$ 5,55 / \mathrm{kg})$ and the average price of 1 $\mathrm{kg}$ of sweet potato $(\mathrm{R} \$ 1,50 / \mathrm{kg})$, marketed in the
CEASA produce distribution center - São Luís, $M A$, in 2012. This RE was equated with the first derivative of the regression model adjusted for the production of commercial sweet potato root and $\mathrm{P}_{2} \mathrm{O}_{5}$ doses.

With the average data of the evaluated characteristics, analysis of variance ( $F$ test), according to the proposed design and polynomial regression analysis were conducted, opting for the most significant adjustment equation. We used the AGROESTAT statistical program, developed by the Exact Sciences Department, College of Agricultural and Veterinary Sciences of Unesp, Jaboticabal Campus. The graphics were generated in Microsoft Excel.

\section{Results and Discussion}

The phosphorus levels significantly influenced the characteristics soil $\mathrm{P}$ content, aerial part dry matter, tuberous root dry matter and total tuberous root productivity. However, there was significant polynomial equation adjustment for all characteristics (Table 1).

Table 1. Analysis of variance and polynomial regression for the characteristics soil phosphorus content after sweet potatoes harvest (TSP), and foliar P content (TFP), aerial part (DMAP) and root (RDM) dry matter and total (TP) and commercial (CP) productivity of the sweet potato 'Beauregard', according to the phosphorus levels.

\begin{tabular}{lcccccc}
\hline $\begin{array}{c}\text { phosphorus doses } \\
\left(\mathrm{kg} \mathrm{ha}^{-1} \text { of } \mathrm{P}_{2} \mathrm{O}_{5}\right)\end{array}$ & $\begin{array}{c}\text { TSP } \\
\left(\mathrm{mg} \mathrm{dm}^{-3}\right)\end{array}$ & $\begin{array}{c}\text { TFP } \\
\left(\mathrm{g} \mathrm{kg}^{-1}\right)\end{array}$ & $\begin{array}{c}\text { DMAP } \\
\left(\mathrm{g} \mathrm{m}^{-2}\right)\end{array}$ & $\begin{array}{c}\text { RDM } \\
\left(\mathrm{g} \mathrm{m}^{-2}\right)\end{array}$ & $\begin{array}{c}\text { TP } \\
\left(\mathrm{kg} \mathrm{m}^{-2}\right)\end{array}$ & $\begin{array}{c}\text { CP } \\
\left(\mathrm{kg} \mathrm{m}^{-2}\right)\end{array}$ \\
\hline 0 & 12.25 & 3.75 & 0.23 & 0.10 & 1.24 & 0.95 \\
60 & 33.00 & 4.06 & 0.27 & 0.15 & 1.45 & 1.12 \\
120 & 41.00 & 4.15 & 0.46 & 0.17 & 2.62 & 1.82 \\
180 & 45.25 & 4.24 & 0.31 & 0.18 & 2.40 & 1.51 \\
240 & 57.50 & 4.38 & 0.20 & 0.16 & 2.22 & 1.67 \\
300 & 60.00 & 4.61 & 0.18 & 0.12 & 2.03 & 1.43 \\
\multicolumn{7}{c}{$\mathbf{F}$ Values } \\
Treatments & $34.60^{* *}$ & $1.20^{\text {ns }}$ & $6.29^{* *}$ & $30.67^{* *}$ & $5.38^{* *}$ & $1.89^{\text {ns }}$ \\
1st order Regression & $160.74^{* *}$ & $5.75^{*}$ & $3.18^{\text {ns }}$ & $12.92^{* *}$ & $9.45^{* *}$ & $30.92^{* *}$ \\
2nd order Regression & $7.37^{*}$ & $0.06^{\text {ns }}$ & $16.23^{* *}$ & $135.45^{* *}$ & $11.81^{* *}$ & $33.16^{* *}$ \\
3rd order Regression & $1.58^{\text {ns }}$ & $0.21^{\text {ns }}$ & $2.23^{\text {ns }}$ & $0.41^{\text {ns }}$ & $0.04^{\text {ns }}$ & $0.05^{\text {ns }}$ \\
\hline C.V. (\%) & 14.38 & 12.61 & 28.45 & 7.36 & 22.6 & 34.90 \\
\hline **, ns = significant at 1\%, 5\% and not significant at 5\% by the F test, respectively.
\end{tabular}

The averages of phosphorus content in the soil adjusted to the quadratic regression model, verifying increments until the estimated dose of $280 \mathrm{~kg} \mathrm{ha}^{-1} \mathrm{P}_{2} \mathrm{O}_{5}$ to yield a maximum level of $55.1 \mathrm{mg} \mathrm{dm}^{-3}$, there being a slight decrease at the highest dose (Figure 1).

For foliar $\mathrm{P}$, there was adjustment of the averages to the first-order regression model, in which a linear increase was observed according to the $\mathrm{P}$ dose applied. As a result, there was directly proportional relationship between the increase in the $P$ supply and its content in the leaf, the lowest level, $3.8 \mathrm{~g} \mathrm{~kg}^{-1} \mathrm{P}$ in the leaf dry matter observed when $\mathrm{P}$ was not applied in the soil, and the maximum content, $4.6 \mathrm{~g} \mathrm{~kg}^{-1}$, with the highest dose applied, $300 \mathrm{~kg} \mathrm{ha}^{-1} \mathrm{P}_{2} \mathrm{O}_{5}$ (Figure $1)$, corresponding to a $21 \%$ increase.

The leaf $\mathrm{P}$ content of plants, fertilized with 
$P$ or not, is located in the proper range, between 2.3 and $5.0 \mathrm{~g} \mathrm{~kg}^{-1}$ for this vegetable, according to Lorenzi et al. (1997). Adequate sweet potato leaf $P$ content, even in soil with low $P$ in which there was a significant use of phosphorus, may be associated with its nutrient uptake efficiency
(EMBRAPA, 1995). Oliveira et al. (2005b), evaluating the $P$ content in sweet potato leaf based on organic and chemical fertilization, reported that the $\mathrm{P}$ concentrations ranged between 3.7 and $4.7 \mathrm{~g} \mathrm{~kg}^{-1} \mathrm{P}$.

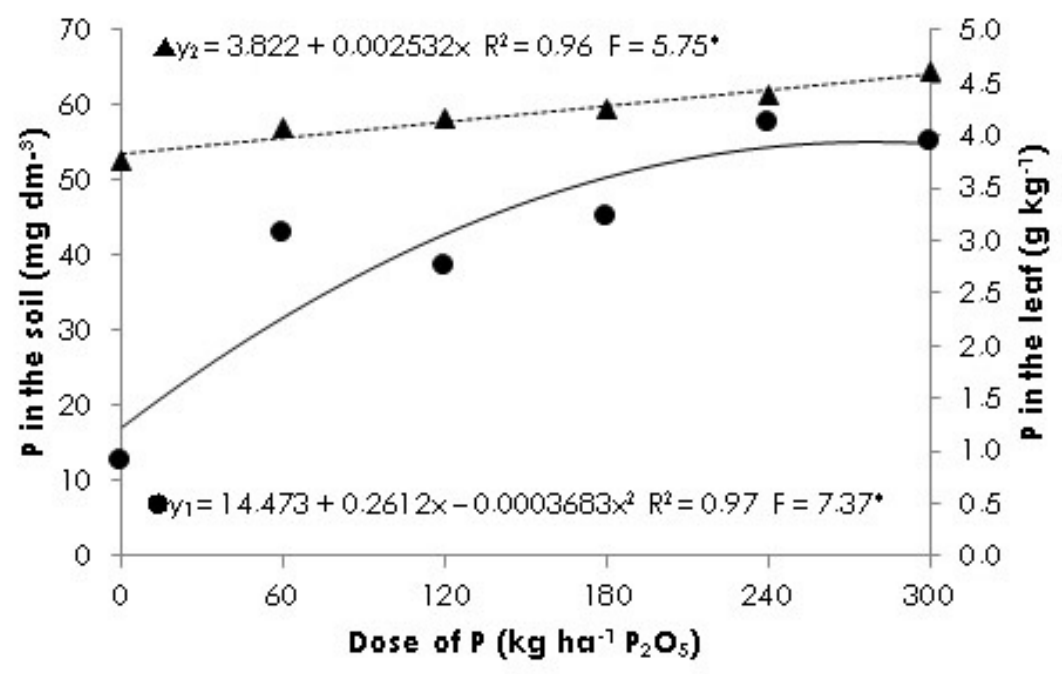

Figure 1. Phosphorus content in the soil $\left(y_{1}\right)$ and leaf $\left(y_{2}\right)$ of the sweet potato according to phosphorus dosage.

For the characteristics dry matter of the aerial part (DMAP) and dry matter of the tuberous root (RDM), there was an adjustment of the averages ovserved to the quadratic regression equation. The lower accumulation of DMAP 10.15 $\left.\mathrm{kg} \mathrm{m}_{-2}\right)$ and RDM $\left(0.13 \mathrm{~kg} \mathrm{~m}^{-2}\right)$ were observed with the highest and lowest dose of $\mathrm{P}$ applied to the soil, respectively (Figure 2).

The maximum DMAP $\left(0.36 \mathrm{~kg} \mathrm{~m}^{-2}\right)$ and the maximum RDM $\left(0.18 \mathrm{~kg} \mathrm{~m}^{-2}\right)$ were obtained with $120 \mathrm{~kg} \mathrm{ha}^{-1} \mathrm{P}_{2} \mathrm{O}_{5}$ and $180 \mathrm{~kg}$ ha-1 P2O5, respectively. Higher doses provided lower accumulations of DMAP and RDM (Figure 2), although the plants preented higher foliar P.

Thus, not finding similar curves that describe adjustment for foliar $\mathrm{P}$ and DMAP contents, starting at $120 \mathrm{~kg} \mathrm{ha}^{-1}$, and foliar $\mathrm{P}$ and RDM, from $180 \mathrm{~kg} \mathrm{ha}^{-1}$, may indicate that sweet potato is sensitive to excessive $\mathrm{P}$ doses, or there may have been interference of the high $\mathrm{P}$ doses in the absorption of other nutrients, thus limiting the sweet potato growth.

Hameda et al. (2011) found that increasing phosphorus dose from 15 to $45 \mathrm{~kg}$ $\mathrm{ha}^{-1} \mathrm{P}_{2} \mathrm{O}_{5^{\prime}}$ significantly increased the aerial part dry matter of the sweet potato. The positive response of sweet potato regarding DMAP possibly occurred due to the rapid availability of nutrients and their absorption by the plant, a fact which provides positive effects of this nutrient in the production of crops in tropical soils.

On the other hand Abdissa et al. (2012) who studied the growth and production of sweet potato according to manure and phosphorus doses, observed a significant interaction between factors, and when manure was not applied the increase in $\mathrm{P}$ doses increased the plant aerial part dry matter. However, when doses of manure equal to or higher than $5 \mathrm{tha}^{-1}$ were applied, the supply of $180 \mathrm{~kg} \mathrm{ha}^{-1} \mathrm{P}_{2} \mathrm{O}_{5}$ yielded plants having a DMAP similar to that obtained without the $P$ application

The mean values for the variables total productivity (TP) and commercial productivity (CP) adjusted to the quadratic regression model (Figure 3).

In relation to the total root yield, the maximum productivity, $2.44 \mathrm{~kg} \mathrm{~m}^{-2}$ (24.4 t ha-1), was obtained with the estimated dose of $190 \mathrm{~kg}$ $\mathrm{ha}^{-1}$ of $\mathrm{P}_{2} \mathrm{O}_{5^{\prime}}$ an increase of $11.6 \%$ compared to 
$1.13 \mathrm{~kg} \mathrm{~m}^{-2}$, obtained without $P$ application. With $300 \mathrm{~kg} \mathrm{ha}^{-1}$ of $\mathrm{P}_{2} \mathrm{O}_{5^{\prime}}$, the sweet potato yield was $1.98 \mathrm{~kg} \mathrm{~m}^{-2}$, the same obtained with $78 \mathrm{~kg} \mathrm{ha}^{-1} \mathrm{P}_{2} \mathrm{O}_{5}$ (Figure 3), a fact that confirms the importance of evaluating the sweet potato response to $\mathrm{P}$, not only as from an agronomic aspect, but mainly from economic and environmental points of view.

Commercial prodictivity increased according to phosphorus fertilization up to the estimated dose of $191 \mathrm{~kg} \mathrm{ha}^{-1}$ of $\mathrm{P}_{2} \mathrm{O}_{5}$ resulting in $1.67 \mathrm{~kg} \mathrm{~m}^{-2}$ of marketable sweet potato (Figure 3). This dose, which maximized commercial productivity, is similar to that proposed by Casali (1999), $180 \mathrm{~kg} \mathrm{ha}^{-1} \mathrm{P}_{2} \mathrm{O}_{5^{\prime}}$ when the soil is low in $\mathrm{P}$. It is important to note that the commercial root yield obtained in the experiment exceeded the average productivity of sweet potatoes for the Northeast region, estimated at 9.3 t ha1 , and also the national productivity average, estimated at $12.1 \mathrm{tha}^{-1}$, according to data from the IBGE (2014).

Doses of $\mathrm{P}_{2} \mathrm{O}_{5}$ higher than $191 \mathrm{~kg}$ $\mathrm{ha}^{-1}$ provided a decrease in the commercial productivity of tuberous roots. With the highest dose evaluated $\left(300 \mathrm{~kg} \mathrm{ha}^{-1} \mathrm{P}_{2} \mathrm{O}_{5}\right)$, the commercial yield reduction was $15 \%$ compared to the maximum obtained. The dose of $191 \mathrm{~kg} \mathrm{ha}^{-1} \mathrm{P}_{2} \mathrm{O}_{5^{\prime}}$ which maximized the commercial productivity, increased productivity without phosphorus application to the sweet crop potatoes by $85 \%$, $0.9 \mathrm{~kg} \mathrm{~m}^{-2}$ (Figure 3).

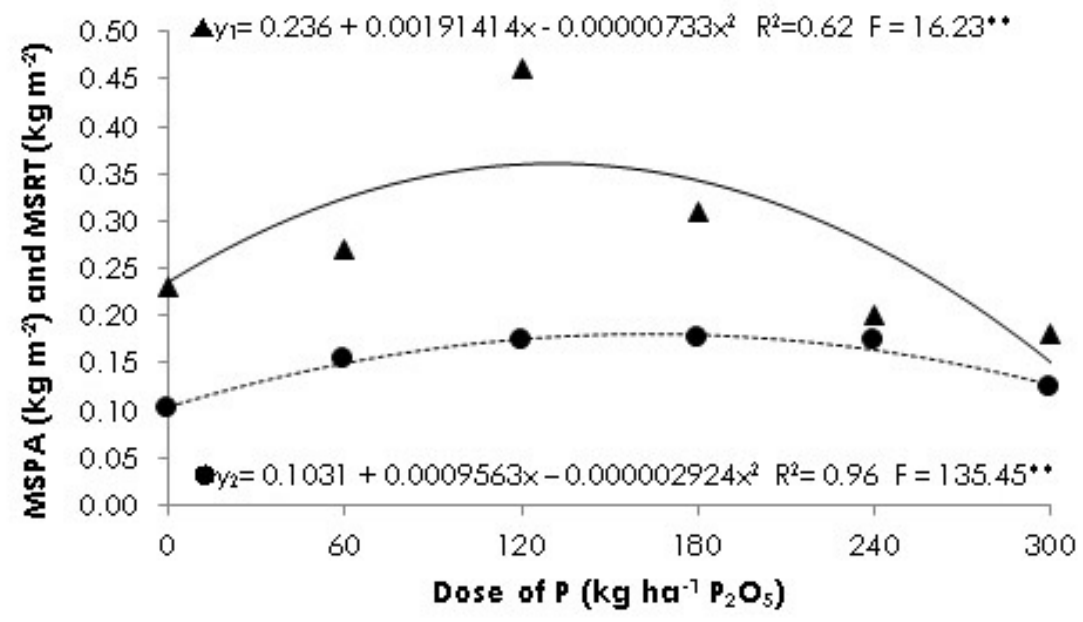

Figure 2. Dry matter of the aerial part $\left(D M A P, y_{1}\right)$ and dry matter of the tuberous root $\left(R D M, y_{2}\right)$ at 60 days after planting of Beauregard sweet potato inaccording to phosphorus levels.

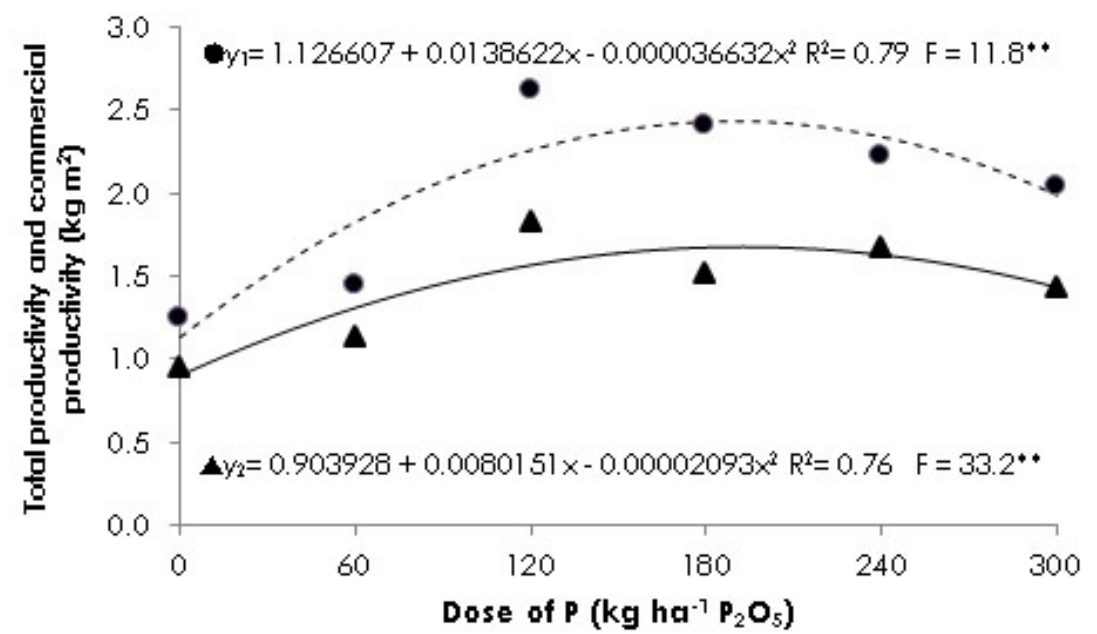

Figure 3. Total productivity $\left(\mathrm{y}_{1}\right)$ and commercial productivity $\left(\mathrm{y}_{2}\right)$ of sweet potato roots according to phosphorus doses. 
These results showed the positive response of Beauregard sweet potato to phosphate fertilization in soil with low soil phosphorus content. Gad \& Hassan (2011) also found significant effect of phosphate fertilization on sweet potato productivity, obtaining $13 \mathrm{tha}^{-1}$ sweet potato with $100 \mathrm{~kg} \mathrm{ha}^{-1} \mathrm{P}_{2} \mathrm{O}_{5}$.

The results corroborate those obtained by other authors. Oliveira et al. (2005b and 2006) and Akinrinde (2006), evaluating the response of sweet potato to $\mathrm{P}$ doses, also observed quadratic adjustment of commercial root yield through increased $P$ dosage, and a maximum yield of 23.5 and $18,7+\mathrm{ha}^{-1}$ achieved with 259 and 210 $\mathrm{kg} \mathrm{ha}^{-1} \mathrm{P}_{2} \mathrm{O}_{5}$, respectively. Hameda et al. (2011), evaluating $P$ doses from 0 to $45 \mathrm{~kg} \mathrm{ha}^{-1}$, found an increase in total and commercial yield of sweet potato of 8 and $20 \%$ when 15 and $45 \mathrm{~kg} \mathrm{ha}^{-1}$ $\mathrm{P}_{2} \mathrm{O}_{5}$ was applied, respectively, compared that obtained without applying $P$.

Reductions in total and commercial productivity with $\mathrm{P}_{2} \mathrm{O}_{5}$ doses above $191 \mathrm{~kg} \mathrm{ha}^{-1}$ probably occurred due to the increased salinity resulting from high fertilizer concentrations reducing the growth of tuberous roots and/or the unavailability of other nutrients. The higher crop productivity does not depend on the fertilizer highest dose, but on the best balance among all the nutrients. Nutritional imbalance impairs the absorption of essential nutrients by the sweet potato, resulting in lower tuberous root yield.

The total and commercial productivity due to the increase in $P$ doses accompanied the DMAP accumulation, but diverged from the continuous increase observed for foliar P content. This result is consistent from the physiological point of view, because the plants have their productive potential defined by serving the growth potential.

The economic optimum $P$ dose for commercial productivity of sweet potato was 104 $\mathrm{kg} \mathrm{ha}^{-1} \mathrm{P}_{2} \mathrm{O}_{5^{\prime}}$ corresponding to $55 \%$ of the dose responsible for the maximum yield of commercial roots. With the economically optimum dose there was a reduction of $54.4 \%\left(191 \mathrm{~kg} \mathrm{ha}^{-1}\right.$ to $104 \mathrm{~kg} \mathrm{ha}^{-1} \mathrm{P}_{2} \mathrm{O}_{5}$ ) in the dose that maximized the productivity, however, obtaining $90 \%$ maximum productivity.

Phosphorus accumulation in the dry matter aerial part (PDMAP) and dry tuberous root matter (PRDM), which equates to the phosphorus export and the total accumulation of phosphorus in the plant dry matter (TPDM) were significantly influenced by the treatments. We verified that the averages adjusted to verified to a quadratic equation regarding the accumulations of PDMAP, PRDM and TPDM (Table 2).

Table 2. F values, significances, coefficients of variation and average of characteristics phosphorus accumulation in the aerial part dry matter (PDMAP), phosphorus content in the tuberous root dry matter (PRDM), the total accumulation of phosphorus in the plant dry matter (TPDM) according to phosphorus doses.

\begin{tabular}{lccc}
\hline $\begin{array}{c}\text { Phosphorus doses } \\
\left(\mathrm{kg} \mathrm{ha}^{-1} \mathrm{P}_{2} \mathrm{O}_{5}\right)\end{array}$ & $\begin{array}{c}\text { PDMAP } \\
\left(\mathrm{g} \mathrm{m}^{-2}\right)\end{array}$ & $\begin{array}{c}\text { PRDM } \\
\left(\mathrm{g} \mathrm{m}^{-2}\right)\end{array}$ & $\begin{array}{c}\text { TPDM } \\
\left(\mathrm{g} \mathrm{m}^{-2}\right)\end{array}$ \\
\hline 0 & 0.26 & 0.13 & 0.40 \\
60 & 0.60 & 0.31 & 0.91 \\
120 & 0.77 & 0.44 & 1.21 \\
180 & 0.76 & 0.52 & 1.29 \\
240 & 0.59 & 0.56 & 1.16 \\
300 & 0.25 & 0.55 & 0.81 \\
\hline & & $\mathbf{F ~ v a l u e s}$ & $19.94^{* *}$ \\
\hline Treatments & $14.58^{* *}$ & $21.79^{* *}$ & $20.11^{* *}$ \\
\hline 1st order Regression & $0.33^{\text {ns }}$ & $60.25^{* *}$ & $75.86^{* *}$ \\
2nd order Regression & $54.79^{* *}$ & $9.73^{* *}$ & $1.19^{\text {ns }}$ \\
3rd order Regression & $3.09^{\text {ns }}$ & $20.51^{* *}$ & 15.67 \\
\hline C.V. (\%) & 25.77 & 21.45 &
\end{tabular}

With the estimated dose of $191 \mathrm{~kg} \mathrm{ha}^{-1}$ $\mathrm{P}_{2} \mathrm{O}_{5}$, which maximized commercial productivity, the accumulation of $P$ in the areial part and tuberous roots were 0.75 and $0.53 \mathrm{~g} \mathrm{~m}^{-2}$, respectively (Figure 4), corresponding to 58 and
$42 \%$ of the total accumulated by the sweet potato plant.

The highest amounts of $P$ were accumulated in the shoot of the sweet potato, followed by the root. The maximum accumulated 
in shoots was $0.79 \mathrm{~g} \mathrm{~m}^{-2}$ and in the root it was $0.56 \mathrm{~g} \mathrm{~m}^{-2}$, reached at doses of 150 and $259 \mathrm{~kg}$ ha $^{-1} \mathrm{P}_{2} \mathrm{O}_{5^{\prime}}$, respectively. Divergent results were observed by Echer et al. (2009), who found that most of the $\mathrm{P}$ is present in the tuberous root, the main drain for plant assimilates.

Considering the $24.4 \mathrm{tha}^{-1}$ sweet potatoes harvested at the maximum productivity, the $P$ extraction was $0.22 \mathrm{~kg} \mathrm{t}^{-1}$ of sweet potato.

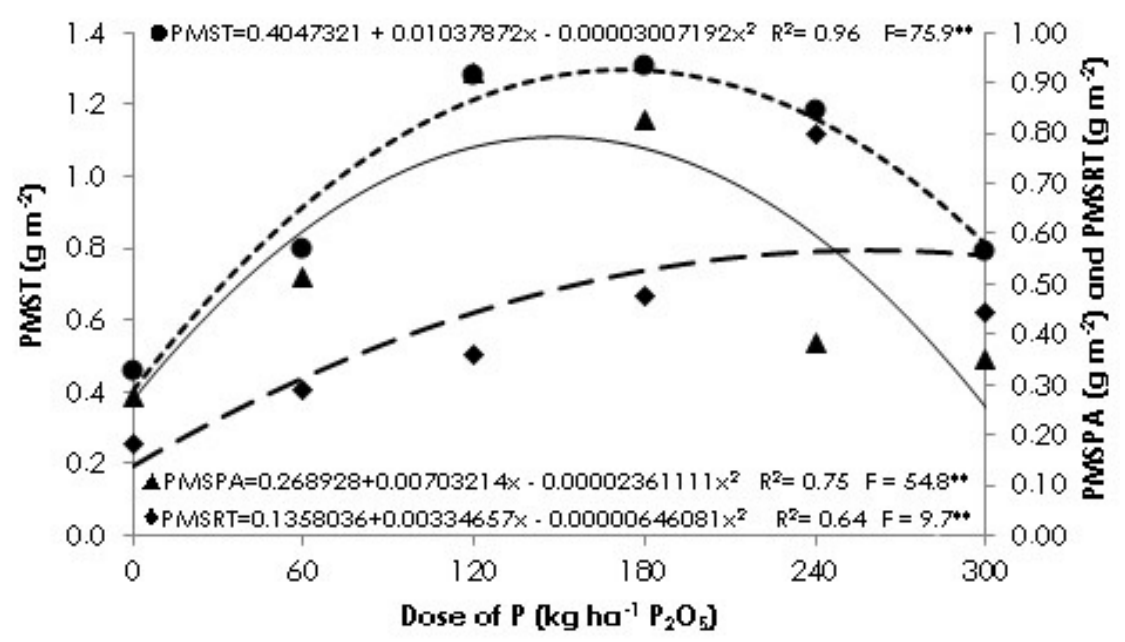

Figure 4. Total phosphorus accumulation in plant (TPDM), in the areial part dry matter (PDMAP) and in dry matter of the tuberous root (PRDM) in sweet potato, according to phosphorus levels.

\section{Conclusions}

Considering the climatic and soil characteristics in which the study was conducted, we conclude that the sweet potato variety Beauregard responds positively to fertilization, presenting commercial production maximized by a $\mathrm{P}_{2} \mathrm{O}_{5}$ dose of $191 \mathrm{~kg} \mathrm{ha}^{-1}$.

The optimum economic dose of $\mathrm{P}$ corresponds to $104 \mathrm{~kg} \mathrm{P}_{2} \mathrm{O}_{5} \mathrm{ha}^{-1}$.

The areial part and roots accumulated 58 and $42 \%$ of the total $P$ accumulation in the plant, or 0.79 and $0.56 \mathrm{~g} \mathrm{~m}^{-2}$, respectively.

\section{References}

Abdissa, T., N. Dechassa, Y. Alemayehu. 2012. Sweet potato growth parameters as affected by farmyard manure and phosphorus application at Adami Tulu, Centra Rift Valley of Ethiopia. Agricultural Science Research Journal 2:1-12.

Akinrinde, E.A. 2006. Phosphorus fertilization effect on dry matter production and biomass partitioning in sweet potato (Ipomoea batatas) grown on an acidic loamy-sand Alfisol. Journal of Food Agriculture and Environment 4:99-104.

Alves, A.U., Oliveira, A.P., Alves, E.U., Oliveira, A.N.P., Cardoso, E.A., Matos, B.F. 2009. Manejo da adubação nitrogenada para a batata-doce: fontes e parcelamento da aplicação. Ciência e Agrotecnologia, 33:1554-1559.
Bailey, J.S., Ramakrishna, A., Kirchhof, G. 2009. An evaluation of nutritional constraints on sweet potato (Ipomoea batatas) production in the central highlands of Papua New Guinea. Plant and soil 316: 97-105.

Bataglia, O. C., Furlani, A.M.C., Teixeira, J.P.F., Furlani, P.R., Gallo, J.R. 1983. Métodos de análise clinicas de plantas - Boletim técnico n. 78.41 p. Instituto Agronômico de Campinas, Campinas, São Paulo, Brasil.

Casali, V.W.D. 1999. Batata-doce. p. 180. In: Ribeiro et al. (eds.) Recomendação para uso de corretivos e fertilizantes em Minas Gerais - $5^{a}$ aproximação . Comissão de Fertilidade do Solo do Estado de Minas Gerais, Viçosa, Minas Gerais, Brasil.

EMBRAPA - EMPRESA BRASILEIRA DE PESQUISA AGROPECUÁRIA. 1995. Cultivo da batatadoce (Ipomoea batatas (L.) Lam) - Instruções Técnicas, 7. $3^{\circ}$ ed. Ministério da Agricultura, do Abastecimento e Reforma Agrária, Empresa Brasileira de Pesquisa Agropecuária (EMBRAPA), Centro Nacional de Pesquisa de Hortaliças (CNPH), Brasília, Brasil.

Echer, F.R., Dominato, J.C., Creste, J.E. 2009. Absorção de nutrientes e distribuição da massa fresca e seca entre órgãos de batata-doce. Horticultura Brasileira 27:176-182.

Gad, N., Hala, K. 2008. Response of sweet potato (Ipomoea batatas L.) plants to different levels of cobalt. Australian Journal of Basic and Applied 
Sciences 2:949-955.

Hameda, S.E.A., Dean, S.A., Ezzat, S., Morsy, A.H.A. 2011 . Responses of productivity and quality of sweet potato to phosphorus fertilizer rates and application methods of the humic acid. International Research Journal of Agricutural Science and soil Science 1:383-389.

IBGE - Instituto Brasileiro de Geografia e Estatística. Lavoura temporária no ano 2012. 2014. http// www.ibge.gov.br/estadosat/temas/ < Acesso em 20 ago. 2014>

LORENZI, J.O.; MONTEIRO, P.A.; MIRANDA FILHO, H.S.; RAIJ, B. van. Raízes e tubérculos. In: RAIJ, B. van.; CANTARELLA, H.; QUAGGIO, J.A.; FURLANI, A.M.C. (eds.). Recomendações de adubação e calagem para o Estado de São Paulo. Campinas: 2. ed. Instituto Agronômico de Campinas, 1997. p. 221-229 (Boletim Técnico, 100).

Mukhopadhyay, S.K., Chattopadhyay, A., Chakraborty, I., Bhattacharya, I. 2011. Crops that feed the world 5. Sweetpotato. Sweetpotatoes for income and food security. Food Security 3:283-305.

Natale, W., E.L.M. Coutinho, A. Boaretto, e F.M. Pereira. 1996. Dose mais econômica de adubo nitrogenado para a goiabeira em formação. Horticultura Brasileira 14:196-199.

Oliveira, A.P., Olveira, M.R.T., Barbosa, J.A., Silva, G.G., Nogueira, D.H., Moura, M.F., Braz, M.S.S. 2005a. Rendimento e qualidade de raízes de batata-doce adubada com níveis de uréia. Horticultura Brasileira 23: 925-928.

Oliveira, A.P., Silva, J.E.L., Pereira, W.E., Barbosa, L.J.N. 2005b. Produção de batata-doce e teor de amido nas raízes em função de doses de $\mathrm{P}_{2} \mathrm{O}_{5}$. Acta Scientiarum Agronomy 27:747-745.

Oliveira, A.P., J.E.L da Silva, W.E. Pereira, L.J. das N. Barbosa, A.N.P. de Oliveira. 2006. Características produtivas da batata-doce em função de doses de $\mathrm{P}_{2} \mathrm{O}_{5}$, de espaçamento e de sistemas de plantio. Ciência e Agrotecnologia 30:61 1-617.

Raij, B. van, H., Cantarella, J.A., Quaggio, e A.M.C., Furlani. 1997. Fósforo e potássio. In: B. van Raij et al. (eds.) Recomendações de adubação e calagem para o Estado de São Paulo - Boletim técnico 100. $2^{\circ}$ ed. Instituto Agronômico \& Fundação - IAC, Campinas, São Paulo, Brasil. p. 9-10.

Silva, L.L., Silveira, M.A., Fidelis, R.R., Tavares, R.C., Momenté, V.G, Nascimento. I.R. 2013. Seleção de genótipos de batata-doce quanto à eficiência ao uso do fósforo em solos da região de cerrado. Journal of Biotechnology and Biodiversity 4:356364.
Thumé, M.A., Dias, L.E., Silveira, M.A. da, e Assis, I.R. de. 2013. Níveis críticos foliares de nutrientes de três cultivares de batata-doce, selecionados para a produção de etanol. Revista Ceres, 60:863-875. 